This is the accepted version of the article:

Valverde Contreras, Beatriz; Keese, Alexander (2021), "Between Violence, Racism and

Reform: São Tomé e Príncipe in the Great Depression Years, 1930-7", Journal of

Contemporary History, 56(2), 243-267. DOI: $10.1177 / 0022009420961456$

Published version available at:

https://doi.org/10.1177/0022009420961456

\title{
Between Violence, Racism and Reform: São Tomé e Príncipe in the Great Depression Years, 1930-7
}

\section{Beatriz Valverde Contreras}

Centro de Estudos Sociais, Universidade de Coimbra, Portugal

Alexander Keese

Université de Genève, Switzerland

https://orcid.org/0000-0002-2836-2084

\begin{abstract}
:
The effects of the Great Depression on the important cocoa plantation sector of the archipelago of São Tomé e Príncipe - a Portuguese colonial laboratory for social change in plantation agriculture shifting between coercive practices and attempts at accommodation - were drastic: initially backed by a right-wing authoritarian government, plantation managements lowered workers' wages and made already repressive conditions of worker exploitation worse. This article highlights the processes of degradation in plantation workers' life. However, in ways that might seem paradox at first glance, the crisis years of the 1930s also opened the ways to changes in social experiences in the plantations.

Labour inspectors were increasingly called upon to scrutinize existing abuses on the plantations, and although this might have been in the first phase simply lip service to certain international debates on good standards in colonialism, inspectors internalized the need for reform and turned out to be critical observers. At the same time, the workers expanded their repertoire of responses - from individual resistance to ever betterorganized escape strategies and the manipulation of offers of settlement schemes for small groups of workers. By 1937, these trends were important precursors to changes that would achieve their full impact in the 1950s.
\end{abstract}

\section{Keywords:}

Forced labour, Great Depressions, migrant workers, plantations, Portuguese colonialism, São Tomé e Príncipe 
In February 1934, the plantation worker Regula went to the labour department (curadoria) in the city of São Tomé to ask for a one-year extension of his contract. Regula demanded, however, that he receive his entire monthly wages at once, instead of accepting that half of it would be paid out as a bonus only after the completion of his contract and his subsequent return to his Angolan region of origin (which would have been the established practice, though unpopular with the workers). The labour inspector agreed wholeheartedly. He commented that

I consented to this wish not only because it seemed reasonable to me, but also to avoid the labourer forming a bad impression and leaving the department, and subsequently abandoning the farm, as so frequently happens, and out of the most futile motives, and even spreading propaganda amongst his comrades, and - who knows? - inciting them to revolt, in a revolt that could have dire consequences, with a repetition of events similar to those occurring in Príncipe in 1932. 1

The very notion of satisfying African plantation labourers, who had been introduced mostly through forced recruitment into São Tomé e Príncipe, a major cocoa-producing and plantation island colony in Central Africa, seems remarkable, and certainly during a period that counts as one of the darkest of the notorious cocoa archipelago during the twentieth century. After the storm of an international campaign against 'slave cocoa' from the Portuguese empire had cleared in the 1920s, plantation management and colonial agents managed to maintain a repressive system into the years of the Great Depression and beyond. $\underline{2}$

The plantations (called roças in the local terminology) in São Tomé e Príncipe changed in the first three decades of the twentieth century from estates controlled locally (and partly still owned by local African elites) to production sites, many of which (notably the more important ones) were owned by banks and companies mainly based in Portugal. Before the Second World War, labourers came from Angola and Mozambique (and in considerably smaller numbers from Cabo Verde, prior to the 1940s when this group became by far the majority amongst plantation workers). Depending on the established rules, contracts were for three or five years. In theory, recruitment was voluntary, repatriation at the end of the contract was mandatory, half of the wages were paid out on a monthly basis (with the other half being provided after the completion of the contract as a 'bonus'), and the labour inspector in the island (the curador, reporting directly to the governor) was, in principle, to protect workers from mistreatment. $\frac{3}{2}$ In practice, respect for these provisions remained weak. At first glance, all the ingredients were present for a 
system in which no pressures for change were ever formulated, and where plantation workers had no chance to defend themselves against abuses and repression.

The installation from 1926 of the Estado Novo (the New State) in Portugal, a right-wing authoritarian political regime, theoretically made it even easier for Portuguese colonial institutions to help Portuguese firms, white landlords and their managers in exploiting the African workforce. When the effects of the Great Depression hit the archipelago, with a massive decline in producer prices ${ }^{4}$, the changes to standards (and the cutting of wages) were also simpler to implement than elsewhere: migrant contract workers lost a drastic 50 per cent of their previous standard wage levels. Moreover, the already well-known problems of the lack of repatriation of labourers finishing their contract, 'the most problematic issue of the labour force in São Tomé e Príncipe' (and a breach of stipulated contract terms by the employers and the colonial state, which, previously, no one really cared about on the administrative side) once again became more acute. $\frac{5}{}$ Even colonial officials in Angola and Mozambique protested against harsh practices for African subjects coming from their colonies and complained about 'bonuses' that were withheld. $\underline{6}$

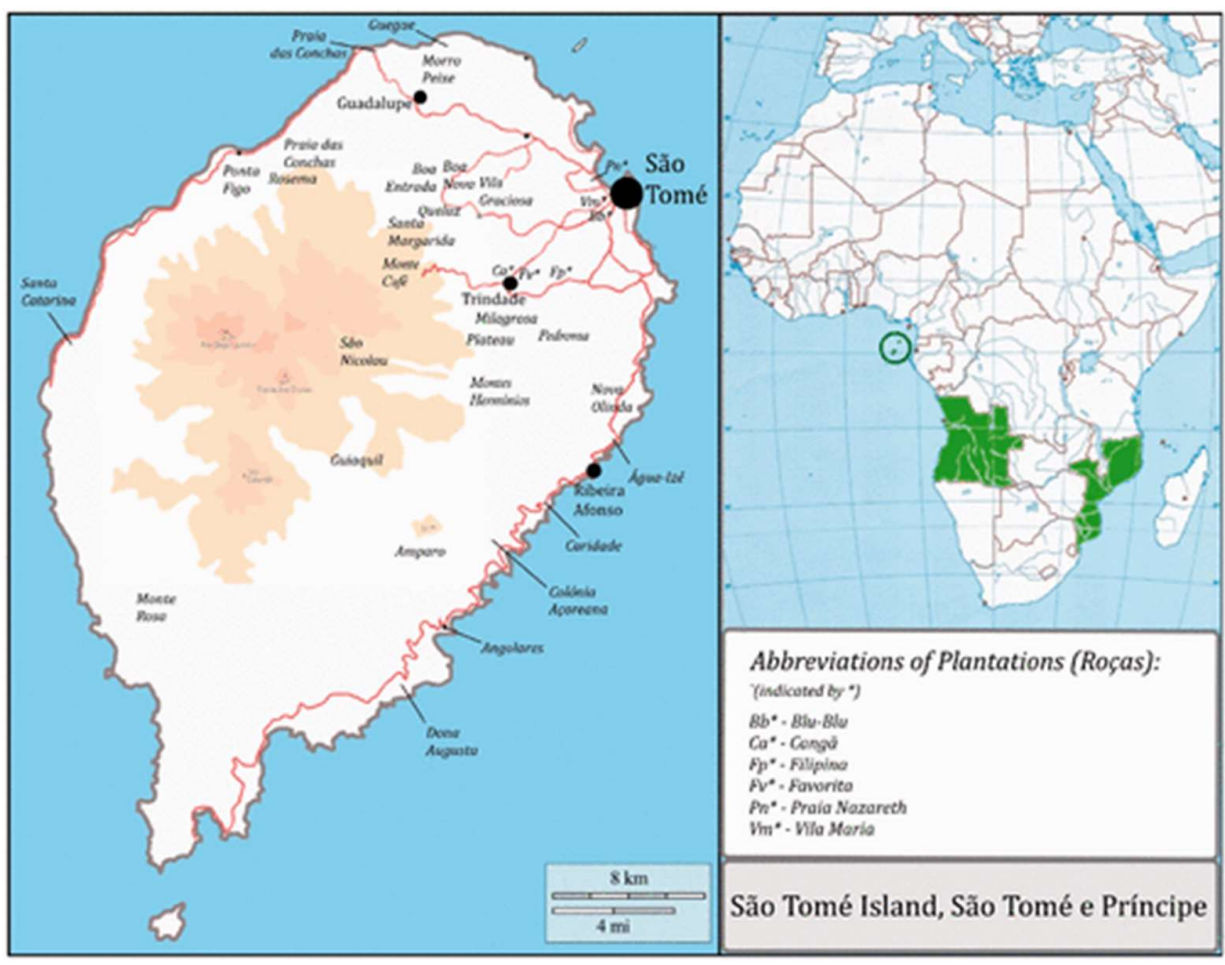

Figure 1 This map is based on a map provided by d-maps.com, available under https://dmaps.com/m/africa/saotome/saotome05.gif. 
But the social experience of decline and worsening conditions on the roças was far more complicated for the decade of the 1930s. $\stackrel{7, \underline{8}}{ }$ While cooperation between Portuguese colonial officials and plantation owners went on in principle, there were countercurrents and internal opposition. ${ }^{9}$ At the same time, the plantation workers, the serviçais, found ways to react on the new hardships. Between 1930 and 1937, they devised new strategies, and intensified others, to cope with the experience of social decline. Changes in the everpresent issue of flight and escape, but also in violence on the plantations and in interactions of plantation workers with the 'native' African population of the islands the nativos, also, initially in pejorative sense, called forros - appeared in complicated patterns, which have not been studied so far.

In this article, we will try to understand the relationship between a wide panorama of reactions of plantation labourers, and the efforts of a labour administration changing positions practically against the odds, pressured by the idea of 'good standards' during this crisis period. There has been practically no analysis so far of the 1930s in São Tomé e Príncipe, and the only important monograph, a masterful structural history by Augusto Nascimento, which nevertheless is mainly based on the Francisco Mantero papers in the Portuguese Arquivo Histórico Ultramarino (the Overseas Archives) and which spans a wide period, with a focus on phases prior to 1926, is widely unused in historical research. $\frac{10}{}$ Nascimento principally argues that the owners and managers of the plantations (often with the connivance of the administration in the colony) tried to accommodate the plantation workers up to a certain point, making of the relations between 'black' labourers and 'white' staff a complicated mix somewhere between violence and repression, creating an identification with the plantation, and, especially, maintaining a rift between plantation workers on the one hand and the other 'black' populations of São Tomé e Príncipe on the other. $\stackrel{11}{ }$ Through this analysis, and an appreciable body of archival sources, Nascimento thereby challenges the historical part of the $\mathrm{PhD}$ thesis of Pablo Eyzaguirre, which argued for a clearer dichotomy between 'white' masters and 'black' subjects in the archipelago. $\frac{12}{}$ Nascimento's interpretation also updates William Gervase ClarenceSmith's classic observations on labour conditions in the roças before 1914. $\underline{13}$

But Nascimento's account remains very schematic on developments in the 1930s, and it tends to make the case for simple continuities. $\frac{14}{}$ This view would need to be qualified. Our approach will, therefore, allow us to arrive at a much more detailed account of workers' behaviour and administrative approaches throughout the 1930s. Ultimately, and this is why the São Tomean experience is so interesting, although at first glance it seems 
only to concern a small African island society, the Depression experience of the archipelago illustrates, as a kind of 'extreme laboratory', changing African responses to scenarios of exploitation and violence, and changing colonial attitudes towards unfree labour and control. This makes of a more systematic interpretation of the extreme case a very valuable example for further reflection on colonialism and violence in plantation societies. In that logic, we will first discuss the role of the labour inspectorate as motor for change and the sources related to the process; then we will explain the importance of the São Tomean case for wider reflections on the impact of Portuguese and European colonialism in sub-Saharan Africa; subsequently, we will follow the experiences of change in the 1930s through a detailed analysis of new archival material from the archipelago.

During the 1930s, cocoa export production in São Tomé e Príncipe lost its lucrative character for an entire decade. As the world market price of cocoa bottomed at under 100 US dollars per metric tonne in the early 1930s, the price per metric tonne for export cocoa from São Tomé e Príncipe went down from over 2,200 Portuguese escudos to under 500 escudos in 1940, when it reached an all-time low for the period after the First World War - in a decade in which consumer prices were characterized by a weak deflationary trend. Therefore, while export volumes remained relatively stable, fluctuating around 10,000 metric tonnes until 1937 (only in the late 1930s and during the years of the Second World War were they reduced towards two thirds of the former export volume), plantation companies saw a meltdown of their earnings of up to 75 per cent. $\frac{15}{}$

Plantation managements reacted on this situation in very conservative ways. They did not try to shift the burden of food production to the workers - although, as we will show, the administrative staff illegally reduced the calories per food ration in a number of cases. At the same time, they had long tolerated workers' production in garden plots, and anticipated that scarcer food rations would in any case be supplemented by the workers. Plantations recruited comparably less workers, and they profited from the administrative decree reducing the monthly wage to half of its earlier value. $\frac{16}{}$

While the reactions and decisions of workers are intimately linked to the organization of labour in the plantations, which involves the beliefs and behaviour of white staff, and the interests of 'black' overseers, their experience was also connected to the administrative control of labour conditions as institutionalized in the curadoria. ${ }^{17}$ Created in 1878 , this local labour inspectorate was at times just waving through labour contracts of the different groups of forced seasonal migrants and sanctioning labour abuses. In the period between 
1910 and 1926, more debate took place within colonial administrations about the needs of better protection for workers. These positions were often half-hearted at best and the degree of intervention of curadores was in any case limited, as they were in a weak position when facing plantation owners and did often not even have the support of the rest of the colonial administration in the territory. However, the question of good standards was raised. In 1926, with the fall of the Portuguese Republic, the idea of increasing workers' protection lingered on; when social conditions fell back to a dramatic low following the effects of the Great Depression, labour inspectors claimed that something had to be done. $\frac{18}{}$ It is certain that in the 1930 s, pressures on the labour inspectorate to modernize came from internal debate and observations in São Tomé e Príncipe (and other colonies), while after the Second World War, calls for concessions and 'good standards' were rather formulated within a small group of reformers in Lisbon. $\frac{19}{}$ But a number of inspectors in the colonies were already committed to the improvement of standards in the previous decade. Moreover, in the 1930s the labour inspectors tried to deal with the crisis situation by focusing on the permanent settlement (fixação) of former contract workers, whose skills and engagement were said to be a possible alternative to the constant renewal of a coerced labour force from outside. But the difficulties of such settlement arrangements were notorious. Exasperated, the labour inspector in 1933 insisted that clear incentives for African workers were necessary, and that the plantation owners were simply unwilling even to consider them. 'The problem is that the majority of agriculturalists are living in the past, and everything that looks like a bit more freedom and rights for the workers is for them synonymous with a breach of discipline,' the inspector held. $\underline{20}$

The study of São Tomé e Príncipe's history is conditioned by an almost complete lack of analysis of the archival documentation that can be found in the archipelago. Augusto Nascimento and William Gervase Clarence-Smith used some of the files in an earlier period (i.e., before the processes of reorganization of the National Archives that took place early in the 2000s) but mainly relied on (private) archives available in Lisbon. Another principal scholar of São Tomé e Príncipe's (more recent) history, and especially of São Tomean society and its 'native' elites - Gerhard Seibert - has not really used the archives for his interpretation. $\underline{21}$ Two studies of previously unknown archival documentation looking at changes in conditions in the plantations between 1940 and 1976 have appeared in recent years, but the 1930s have not been interpreted specifically in any more recent work. $\underline{22}$ 
For São Tomé e Príncipe, oral evidence can no longer substantially contribute to these interpretations. $\underline{23}$ Oral accounts are of course most interesting for understanding the picture created by former plantation workers of the end of colonial rule and the plantation system, of nationalization after independence, but especially of marginalization of plantation workers as second-class residents within independent São Tomean society. We learn from such information that conditions were fundamentally problematic until the 1950s, but normally the remaining interviewees of a suitable age have lived through the years of improvement, with conditions becoming better before 1974 and with independence leading to a massive socio-economic crash: the criticism of colonial exploitation frequently comes across as conforming to a standard narrative, while these individuals confirm that they experienced relatively little violence and give a nostalgic discussion of the 1960s and early 1970s. $\frac{24}{}$ However, this does not help us to get beyond experiences of the late colonial state - in other words, given the constant introduction of new generations of workers, and the massive change in labour conditions and of the regions of origin of those workers, it is difficult to get to useful oral accounts for the period after 1960, but virtually impossible to obtain even a glimpse of the period before. (That conditions in the archipelago were perceived as massively abusive by workers can clearly be analysed from the voices found within colonial documentation, while in oral accounts this only emerges as a streamlined, distant horror narrative.)

Conversely, the local archives offer vast amounts of evidence for the period of the Great Depression. The files of the labour inspectorate in particular, the curadoria series of São Tomé e Príncipe's National Archives, constitute dossiers whose accounts can be deconstructed to get access to the workers' experiences. First and foremost, we need to assert that 'African voices' are part of these files, through the letters of complaint sent by workers and the transcripts of workers' declarations within the inspectorate. Obviously, the view of the workers is distorted by the intervention of scribes and of letter writers -

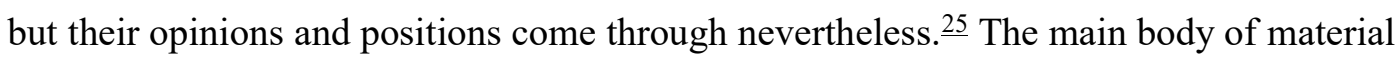
consists of processes initiated by the labour inspectors, which are very useful for understanding the experiences of labourers, and even their subaltern strategies. Also very helpful is the interpretation of tensions between the views of different officials, which allow us to filter out the scandals and malfunctions of imperial administration. $\underline{26}$ But in the São Tomean case, we can speak for the 1930s of a real gap between the opinions of labour inspectors on the one hand and those of plantation managers and 'white' employees on the other; although mutual dependencies continued and although the 
colonial administration still tolerated a great number of abuses that were clearly punishable following Portuguese legislation, this conflict helps us to shed light on abuses against African workers. $\frac{27}{}$ Certainly, even labour inspectors such as Afonso de Barros, who as acting labour inspector in 1935 signed a number of highly critical reports that are of considerable value for interpreting the living conditions of serviçais, were characterized by racist and authoritarian (if paternalistic) positions. $\underline{28}$ Even so, the internal divisions over the intensity of repression and the measures that were tolerated help us to learn about the names and situations of workers, and, to a degree, to reconstruct their experiences.

An archipelago that had a population between approximately 60,000 in the 1930s, and a maximum of 90,000 at independence in 1975, might seem of less relevance for understanding coerced labour under colonial rule in Africa - but São Tomé e Príncipe serves as an important case. Linked to Angola, Mozambique and Cabo Verde through the plantation labour that was mostly forcibly recruited, it also shared in their experiences in labour exploitation. In a way, the archipelago constituted between the mid-nineteenth century and at least 1945 the extreme case for Portuguese colonial rule. After the international anti slave-chocolate campaign of the 1910s, it remained uncomfortably linked to similar accusations against Portuguese forced labour in Angola denounced in the 1920s. Thereby, São Tomé e Príncipe is especially illustrative for collusion between administration and company interests in the exploitation of coerced labour. $\underline{29}$ While Jeremy Ball for sugar cane production close to Benguela, Angola, and Eric Allina for the Mozambique Company have shown some of the effects of such collusion, the islands were a hotspot for those practices, illustrating their possibilities and limits. $\frac{30}{}$ They also provide evidence, in a more concentrated form, of opportunities for resistance that also appeared on the mainland, and of trends towards internal criticism and reformism.

The very existence of any reformist trends within Portuguese colonialism has been challenged; where the debate exists, it principally focuses on the late colonial period between 1945 and 1974. While some studies have managed to point out the role of reformist officials and, especially, attempts to tackle forced labour before it became formally abolished in 1961/62, others have doubted the impact of reformist measures or legislation. $\frac{31}{}$ Yet another current in recent studies on coerced labour and Portuguese colonialism refers to the complex link between international pressures and Portuguese concessions in that field, showing that even those colonial officials who were in doubt 
about the need for labour reforms, wanted to present the Portuguese empire as modern and corresponding to international standards. $\frac{32}{3}$

Much of this research focuses on the social historical experience of African populations, including their capacity to profit from tendencies towards reform. African workers under Portuguese colonial rule, whether coerced or 'encouraged' by the administration or voluntary labourers, took their chances to negotiate with labour inspectors and more benign administrators. Where the path towards improvement remained gridlocked, they often voted with their feet and escaped, and, sometimes like in Angola's Malange district before the start of wider anticolonial guerrilla warfare in 1961, they would revolt against forced labour. $\underline{33}$ São Tomé e Príncipe is a highly interesting case for such wider analysis, as it is possible to show that after independence in 1975, workers in the roças accused the new administration to worsen conditions and to be more repressive than the Portuguese late colonial state. $\underline{\underline{34}}$

However, observations in research on colonial reformism, its chances and its effects, and its experience by African colonial subjects, are mostly limited to Portuguese late colonialism. For the 1930s, it has widely been taken for granted that Africans under Portuguese rule did not hope for improvements, and that Portuguese colonial officials never considered any benign reforms. Even the important new studies by Samuël Coghe on Angola in the interwar period rather tend to highlight heavy-handed Portuguese interventions to battle health problems and malnutrition, but take them as relatively opportunistic and not really in line with reformist thought. $\underline{35}$ Once again, São Tomé e Príncipe emerges as a hotspot where drastic social conditions for workers were particularly visible, and the case allows us to test wider trends.

It is also worthwhile to take the case as part of an even wider panorama of repressive measures and reform attempts that includes African colonies under French and British rule; the view on zones where cocoa production by African smallholders was common might be especially interesting. $\frac{36}{\cdot}$ In the turbulent years of the Great Depression, European administrations, exemplified through the notorious case of the Gold Coast, tried to set up control mechanisms and to reduce export production, although the effects only materialised during the war years. .37 In general, more systematic research on the Great Depression has had its principal expressions in the 1970s for the federation of French West Africa. $\frac{38}{}$ In the following decades, the research focused on a number of specific territorial cases, mainly under British rule - like Northern Rhodesia or Tanganyika - or the very particular South African experience, with its complicated mix between the 
interests of different white and black groups. $\frac{39}{}$ Moses Ochonu has demonstrated for northern Nigeria the complex interplay between peasant reactions and government strategies during the Depression years ${ }^{40}$; he has also pointed to interesting convergences between internal criticism from within the colonial administration and criticism by local elites, in constellations made possible by a less repressive form of colonialism. $\underline{41}$ Even so, and especially as Ochonu's analysis yet stands relatively alone, the São Tomean case is another striking example for convergences.

Finally, the 1930s were also a period in which both British and French colonial governments partly experimented with more liberal approaches and plans for social improvement. If authoritarian Portuguese colonialism of the 1930s can hardly be seen as similar to the reformism of France's left-wing Popular Front between 1936 and 1938, or British plans for colonial development and welfare in the wake of the Hailey Report, we might nevertheless ask if colonial trends in the Portuguese case remained entirely detached from that wider current. $\underline{42}$ Again, São Tomé e Príncipe appears as an excellent case study.

The decline of labour conditions in the wake of the Great Depression hit a group of contract labourers that in 1935, according to the ambitious and probably fairly authentic report by the acting labour inspector, numbered 24,600 individuals, 10,969 of which were Angolan in origin and 10,764 Mozambican; the rest came either from Cabo Verde or were descendants of migrant contract labourers born in the archipelago (socalled tongas according to colonial jargon). ${ }^{43}$ In spite of the atmosphere of decline, and according to estimates formulated by the labour inspectorate, these numbers were far below the employment potential of cocoa export agriculture, for which the official calculated a future total need of some 38,000 to 40,000 labourers. Less well documented in the research literature is the fact that the crisis also affected 'native' (forro) workers, of which more than 1000 were employed as wage workers in the plantations. $\underline{4}$ A number of smaller plantations collapsed entirely in the early 1930s. Their workers were redistributed, and some of them were definitely settled; often, they had hoped to be immediately repatriated and, seeing such hopes crushed, they were increasingly frustrated. $\frac{45}{}$ But even where firms resisted collapse, they had to navigate stormy waters; their owners and managers tried to turn that situation to their advantage, justifying all kinds of illegalities. Plantation administrators created a certain type of master narrative on the decline of their situation - which argued for the need for more repression: they insisted on the debt burden that led a number of plantation firms into bankruptcy, the need 
for more and cheaper workers, and the injustice of the repatriation system for the employers. The administrator of one of the biggest firms, the Companhia Agrícola das Neves, owner of Ponta Figo and Rosema plantations with an impressive 1,500 plantation workers, complained vehemently that 'we have a total of 289 old Angolas, 23 old Mozambiques, and 6 young Mozambiques with contracts which have come to their end',

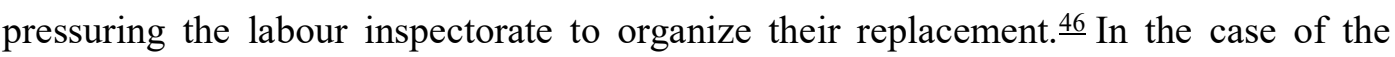
estimated 10,418 Angolan workers still present in São Tomé e Príncipe by 1937, 6000 had arrived between 1927 and 1931, and the other 4400 had come between 1909 and 1922, indicating a breach of all existing rules. $\underline{47}$

Plantation managers were much more ambiguous about the settling of former contract labourers and of tongas - which was, as we have seen, a principal goal of the colonial administration. Their presence varied in terms of numbers; many managers saw them as a nuisance, potentially as dangerous. In some plantations their numbers nevertheless became considerable, but many of the tongas living in the plantations were children such as in places like Caridade or in Guegue. $\underline{48}$ In a big plantation like Monte Café, 20 Angolans and 22 Mozambicans lived there as settlers together with 75 tongas $\underline{49}$; Santa Catarina had 31 Angolan workers and 25 Mozambicans settled, plus 24 tongas in the plantation (of which two had official fixed residence). $\frac{50}{}$ Under notoriously problematic conditions, such settlers would run away. That was the case of Água-Izé, where, in theory, 53 tongas were settled, but 21 escaped. $\underline{51}$ In the small plantations of Java or Cangã, the labour inspectorate learned of only four settled workers and two tongas in the first case, and eight tongas in the second. Other small plantations such as Blu-Blu and Monte Leão had none of any of the two categories. $\frac{52}{}$

In 1931/32, the Portuguese state attempted to stem the tide of economic decline in the export production sector in São Tomé through a series of decrees, starting on 27 July 1931. As we have already seen, the principal strategy was simply to cut wages, leaving the African labourers with the burden of the adjustment (and provoking a number of strong reactions). But this was also, in the biting criticism of Afonso de Barros, inspector of labour four years later, an opportunity to potentially rethink the organization of labour; however, he confirmed, the plantation owners were quite unwilling to consider any modification of the labour system, and certainly not in terms of concessions to the workers:

But, with the laudable exception of an extremely limited number of agriculturalists, nothing was ever attempted and during the awful state of 'every man for himself', 
no particular initiative merited praise during this critical moment, and no technical effort in the study of the soil, and no measures, of fina[n]cial or economic nature that would not have brought as a consequence the gravest and most prominent bad conditions for the colony. $\underline{53}$

Plantation managers disagreed and insisted on the maintenance of laws that were harsher than the repressive colonial standards elsewhere; their strategy for coping with decline was to intensify the more repressive modes of labour extraction. At some plantations, including some of the large ones, such as notorious Água-Izé, the task was left to managers of dependencies to increase production quotas, not only for cocoa, but also for palm oil (which was the case during a scandal at Castello dependency). Some impressive escapes of whole groups were due to conditions becoming drastically more brutal. $\underline{54} \mathrm{At}$ the same time, plantation managers tried to prevent workers fleeing; such as in the roça Nova Olinda where it (again) became an increasingly common practice to lock the plantation workers in for the night. However, this triggered conflicts with the labour inspectorate: the inspector held that the practice had undertones of slavery and was no longer acceptable, as it damaged the good name of Portuguese colonialism. $\frac{55}{}$ Denying workers adequate food was yet another strategy of plantation owners wishing to save resources: dire food conditions were something that reached a negative peak during the years of the Second World War, but the situation was already bad in the second half of the 1930s. In Nova Olinda, subsequent labour inspectors attempted to combat such conditions, although still with little success. The inspectors still tended to regard all workers as possible liars and to not give their stories too much credence. $\frac{56}{}$ But sometimes the worrying stories were supported by hard facts. A laboratory analysis of a typical contract worker's diet ration demonstrated a deficiency of 300 grams of maize flour (fubá), 58 grams of dried fish, and 8 grams of palm oil as compared with established minimum standards. $\frac{57}{}$ And in several cases complaints, such as by workers of São Nicolau plantation, were credible enough to make the inspectorate speak of dreadful conditions. In 1937, such opinions did not yet necessarily lead to any decisive action, but the change of perspective was a start. $\underline{58}$

A prestige issue for the Portuguese empire, including under the Estado Novo, was the idea of offering exemplary health standards in the plantations. Prior to the late $1950 \mathrm{~s}$, actual standards were clearly never particularly high - but in the 1930s, labour inspectors were eager to express their worries about inadequate facilities. A number of plantations, including big complexes such as Santa Catarina, Boa Nova or Ponta Figo, did not have a 
medical doctor at their disposal; frequently, the management called for help from the (rudimentary) public services on the island, which was a temporary solution (the three to four doctors working in the colonial capital of the island did not have the capacity to treat thousands of ill workers). $\frac{59}{}$ Lack of investment was equally evident in the state of some of the plantation hospitals, discussed with horror by the labour inspector. An extreme but not necessarily unusual case was that of Milagrosa plantation, where 'the hospitalized workers were found in a state of absolute absence of any comfort, without blankets to cover them nor beds, and [...] some of them, although officially hospitalized, were encountered engaged in agricultural work'. Although possibly seriously ill, such workers could even be punished for alleged infractions. $\frac{60}{}$ Conditions were similarly dire at Caridade plantation, where the hospital was said to be 'abandoned' by 1932 and not offering any service at all. $\frac{61}{}$

A final tool to boost economic performance was a more standard utilization, or manipulation, of family structures. In some cases, families of workers benefitted from this new situation; and sometimes, such as in the case of plantation worker Maria Rosa from Boa Entrada, contract workers could be reunited with parents who lived outside of the plantation system, sometimes against the will of plantation administrators. $\underline{62}$ In most cases, however, this new generosity seems to have served to reduce payment by considering family unions, and by underpaying the women of nativos. For the case of Amparo plantation close to Ribeira Afonso, we find the detailed instructions and plans for this strategy. $\frac{63}{}$

Harsh labour conditions were nothing new for the archipelago. But their intensification from 1930 onwards also intensified reactions and, at the same time, led to more violence from plantation managers and the forces of order alike. This created a complex backdrop for the ambivalent reform attempts of the labour inspectorate.

In 1936, the labour inspectorate complained about the difficulty of the task that the authorities faced, given the behaviour and reactions of the plantation workers. The principal issue was the omnipresent threat of a workers' exodus from the plantations. In that regard, the smaller island of Príncipe, where there was a massive 'exodus' from the plantations into the town of Santo António, was an important laboratory for what the inspectorate regarded as workers' resistance. For the whole of the archipelago, the labour inspectorate attempted to stop this movement by means of a rigid pass system, which failed entirely..$\underline{64}$ The difficulties of control were one issue, the brutalities of plantation managers quite another. This was seen as especially serious when plantation managers 
also had administrative roles: Afonso de Barros as labour inspector complained about the authoritarian practices of the administrator of Plancas plantation, who also functioned as town ward of Guadelupe, this combination giving him a position of power in the region that was difficult to touch. $\frac{65}{}$ The available police forces in the island numbered only 180 men; moreover, 'native' policemen showed themselves to be unwilling to act against revolting forro residents of the city and the towns, and their number was insufficient to suppress revolts in the roças. $\frac{66}{6}$

Strikes and revolts had been a part of plantation life from the nineteenth century onwards, but the wave of workers' frustration in the 1930s motivated more sustained resistance. Workers also became better organized. In April 1936, Angolan labourers Correia, Munica and Viemba refused to continue to work for Morro Peixe plantation, and successfully attacked a rural police unit sent to arrest them. $\frac{67}{} \mathrm{In}$ the Milagrosa plantation, the dependency São João experienced a number of violent strikes, with strike leader Lucanda threatening the local overseers. $\frac{68}{}$ Smaller plantation units, such as Bom Sucesso dependency of Praia Nazareth plantation, also had to contend with a series of disturbances. $\frac{69}{}$

Plantation administrators, while relying on armed support facilitated by the authorities, tried to downplay the motives of the workers. They essentially blamed violent resistance on the effects of alcohol abuse; thus, in a complaint, the administrator of Monte Café plantation proposed a stricter control of the palm wine business and prohibitive taxes. $\frac{70}{} \mathrm{In}$ some cases, there is empirical evidence showing the relevance of that factor: on 5 October 1932, in the small plantation of Vila Graciosa the entire labour force refused to return to work, fled the plantation, and reappeared in the afternoon very drunk. $\underline{71}$ But elsewhere, violence manifested itself in actual mutinies, such as in 1934 at Quinta de Santo António plantation, where Portuguese troops ultimately arrested the nine heads of the rebellion, Morosande, Catimba, Muamquebe, Chanzela, Muangufo, Chiambo, Paulo, Zage and Selmane. The labour inspector held the European administrator, Armando Figueiredo, responsible for the revolt because of poor conditions. $\frac{72}{}$ In 1935, Vila Maria plantation experienced a mutiny, and the labour inspector again had to mobilize troops. He blamed Acácio de Albuquerque, a relative of the owner, for the dire situation in the roça having led the workers into rebellion. $\underline{73}$

Much more complicated to analyse are the various acts of alleged sabotage, which, according to white plantation staff, were seemingly abundant in the 1930s. It is not easy to interpret these episodes - what to make of the case of José Zuge, a worker who 
deliberately cut down young banana plants in Santa Catarina plantation? ${ }^{74}$ Or that of worker Salupeio at Favorita plantation who on repeated occasions convinced his fellow Angolan workers to refuse to use the machines for the preparation process of the cocoa? $\frac{75}{}$ It is plausible that such acts were a reaction to the repressive conditions, but this is difficult to prove. The labour inspectors of the 1930s, hoping to mollify the workers, did not really know how to respond to these acts. The result is a complex mixture of rigidness and attempted generosity that did not satisfy the administrators, but also seems to have mystified the workers.

In most cases, the violence in the plantations or the frustration of the workers provoked resistance and flight, which were substantially on the increase compared to the decade of the 1920s. In a number of incidents, the conflicts were personal - tonga Anibal and Administrator Manoel Bernardo Ferreira at Santa Margarida plantation attacked each other in a dispute over a local 'mulatto' woman, Armanda, claimed by both men - but many were linked to local conditions. $\frac{76}{}$ Elsewhere, fury about refusals on the part of the administration to repatriate workers was behind unrest and revolts. In Montes Hermínios plantation, a 1931 disturbance was caused by the management's announcement that many workers were either too old for quick repatriation, or ineligible due to having family in the archipelago..$^{77}$ In 1934, the management of the same plantation was more inventive in explaining workers' agitation. When 'leaders' Muquipera, Ruffino and Muenga were caught, they were accused of having tried to cause violence due to being barred from the kitchens as a consequence of frequent thefts. $\underline{78}$

The list of apparently more individual incidents is much longer. At Milagrosa plantation, two workers - Matutussa and Curiuma - attacked plantation staff, with the two separate incidents occurring within the space of three days. $\frac{79}{}$ In Montes Hermínios, tonga Manoel Sabalo was accused of such an attack and was punished with the palmatoada (blows on the hands with a specific broad paddle); at Boa Nova plantation, Mozambican worker Massequel fled the plantation after almost assaulting the overseer. $\underline{80}$ Most frequently, it can be demonstrated that these attacks were a direct reaction to violence experienced, especially brutal beatings. Plantation managers mostly attempted to deflect the accusations. At Favorita plantation, the administrator argued that the worker Cadire had invented the story about his being the victim of an unjust beating; according to the administrator, Cadire had repeatedly abandoned his work at the mill and used plantation chemicals to catch crabs - the punishment would have been light for such a case. .81 Elsewhere, plantation staff accused the workers of self-inflicting wounds. On 
Roça Queluz, plantation workers were hospitalized with wounds sustained from beatings,

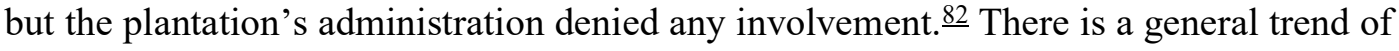
plantation management sending workers to the hospital in town instead of using the health services of the plantations, in order to save funds. $\underline{83}$

Many of the hundreds of cases of corporal punishment per year that were actually known to labour inspectors were very complicated to judge. Protection of female labourers was a problem in that context. Worker Muangute from the Lembá plantation was harshly punished for negligence, but he claimed that the motive was a conflict with the manager about a tonga woman. He explained the inspector that he had paid bridewealth for this woman and arrived with fellow labourers as witnesses; this was difficult for the labour inspector to dismiss. $\frac{84}{}$ In Roça São Nicolau, punishment was inflicted on Angolan worker Quissata, reputed (but only by the white staff) to be dangerous and indisciplined. In reality, the conflict in that plantation came from the overseer's behaviour of violently prohibiting workers from talking during service, which aroused resistance. $\frac{85}{}$ Another category of punishments was (allegedly) a response to 'irrational' violence between workers. Certain 'racial' conflicts - such as in the documented case between Mozambican Pocar and Angolan José Armando at Filipina plantation - seem to have been commonplace, but it is generally difficult to find further information on such violence; for the white plantation staff, this was a welcome excuse to authorize and implement punishments. $\underline{86}$ Alleged (or real) theft was another excuse. A number of single incidents are known about because in the 1930s the labour inspectorate reported on irregularities; at Água-Izé, worker Cambuta was severely punished for theft, the wounds inflicted being so violent that the inspector penalized Manager Ramos with a fine of 200,000 Portuguese Escudos and the two guards involved with 10 days of penal labour. $\frac{87}{}$ In other - and rather frequent - such cases, plantation managers claimed that alleged brutalities in corporal punishment were an outright invention. There is an example of such a strategy in a case from Praia das Conchas plantation: overseer Almazia was accused by the labour inspectorate of having whipped worker Naxifua. The administrator claimed that this was a lie, and that all the overseers denied having been involved; at most there would have been slaps, as all plantation staff would know the rules ... $\frac{88}{}$

But at least Afonso de Barros, as labour inspector, urged a different practice. He advised against violence, which, he insisted, could well lead to widespread discontent amongst plantation workers. $\underline{89}$ Six years earlier, his predecessor as inspector general had admonished the administrator of Colónia Açoriana that '[the] cane, the whip and the baton 
are absolutely prohibited, because they are incompatible with the paternal punishment that we could tolerate'. $\underline{90}$ This inspector held physical punishment to be the main cause of unrest in the plantations. 11 Afonso de Barros intervened in 1934 in the situation of São Nicolau plantation, responding to complaints by tonga worker Joaquina and Angolan worker Quissata; he held that it was fatal to allow overseers and white employees to

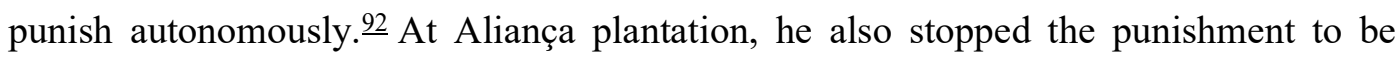
inflicted on one-armed worker Assoma, a tonga, who had been sent to excavate mounds for a week; the inspector claimed this was far too excessive a punishment, and could in any case only be implemented by the labour inspectorate. .93 In the case of Santelmo plantation, a number of workers escaped and reported violence against them by the white employees. Although the labour inspector held this behaviour to be 'a bit outside of the employee's rights', he nevertheless took up a position against unnecessary brutality in the plantation's routines. $\underline{94}$

While Nascimento argues that a certain accommodation of the plantation workers was an early goal, probably already taking effect in the 1890s, our analysis of the $1930 \mathrm{~s}$ correspondence seems to demonstrate that labour inspectors regarded such improvements as relatively recent, suggesting that this decade probably saw a new attempt. It was against this backdrop that the inspector in 1930 admonished the administrator of the plantation of Jou to be more generous in concessions towards his workers (this administrator had explained and defended his harsh reprisals):

I see in your dispatch demands that, today, are only impertinent, unnecessary and that can make us ridiculous, as it has already happened. Let the workers smoke, except, perhaps, in the presence of the owner, who, by the way, should simply pretend not to see anything; let them sing songs, because song is an excellent means to methodize the service and even to mechanize it, to save energy; don't be so strict concerning the issue of the bonnets. S. Tomé is notorious as a kind of militarised compounds, and it is good to finish with that before some 'other power stops it'. $\underline{9}$

In the economic crisis years between 1931 and 1937, the labour inspectorate attempted to stop brutality, even under conditions that made it attractive to plantation managers to increase the exploitation of their workers. In 1938, during a short interlude of less repressive conditions, the acting labour inspector commented that the principal goal in the difficult years had been to accommodate labourers. He claimed that this had at least partly shown success, and in especially visible forms during the visit of the archipelago by Portuguese president, António Óscar Carmona, when a group of workers dressed in 
what was supposed to be 'tribal' garments greeted the president, apparently enthusiastically, as the inspector held. $\frac{96}{}$ At the same time, workers found more systematic strategies of response in the 1930s, ranging from well-planned escapes to manipulation of the increased protection given by the inspectorate.

From 1931 onwards, both episodes of flight and of creation of more stable groups of runaways became ever more intense. This was not comparable to incidents in the archipelago's smaller island of Príncipe, where, as was mentioned earlier, Portuguese armed forces stopped a nascent revolt in 1932, but for the years between 1931 and 1937, we find various armed attacks on São Tomé's plantations by runaway workers. However, the assailants in all the known cases were essentially trying to get access to food. In 1931, such groups repeatedly attacked Pinheira plantation. ${ }^{97}$ In 1932, Trás-os-Montes plantation was the target of an attack by a cattle-robbing gang of refugee workers. $\frac{98}{} \mathrm{In}$ both cases, police and army units had great difficulty in finding and arresting the attackers; all other incidents of the same type seem to adhere to that pattern.

A considerable number of workers fled in the 1930s; São Tomé e Príncipe's plantations had not seen such massive movements for 20 years. The existence of refugee communities in Maroon-like situations and the many more individual trajectories of runaways probably need a detailed analysis of their own. As in the case of Jou plantation, it can be shown that labourers managed to use the instrument of flight strategically, to ultimately force the management to consent to their repatriation. $\underline{99}$ The city of São Tomé became an increasingly frequent destination for such runaways, because rumours circulated that even after being captured as 'vagrants' in town, they would have the possibility to renegotiate their future service and the plantations they would have to work in with the labour inspectorate. There was indeed the chance that the inspectorate would change their places of work; plantation administrators complained strongly against such procedures but the labour inspectors frequently failed to take their comments into account. $\frac{100}{}$ While raids against plantation workers hiding in town and practicing 'vagrancy' remained quite normal - though they did not reach the level of the particularly notorious 'vagrants' hunts in 1924 - the inspectors also tried to avoid provoking local unrest. $\frac{101}{}$ The labour inspectorate went even further. While it was confirmed that plantation workers held clandestine meetings in the city, this could be tolerated as long as such activities took place in open daylight and in the presence of police observers and informers. $\frac{102}{2}$ The insecurity of the labour inspectors in the crisis years thus provided the opportunity for escaped workers and temporary absentees to improve their situation. 
Other local workers also spotted the chance to jump on this train of slightly more liberalism, and to stabilize their situation through petitions. This can be observed in the experience of Xibia, a native of Cuito Cuanavale in Angola, former Santa Adelaide plantation worker of two years, then deposited in Vila Mendes plantation for another three years, and finally for five years in Monte Estoril, where he was brutally beaten by his own account. After that long career as the victim of unlawful but common practices, Xibia escaped and managed to settle as a free labourer in São Marçal plantation, where his previous history was unknown, and the plantation manager was all too happy to install a new worker without all the legally necessary documentation. In view of the new, more liberal trend, the worker now appeared demanding the payment of five years of bonuses from the labour inspector. $\frac{103}{}$ We mainly know of the cases where the labour inspectorate gave a negative response. When Luiza and Joaquim Cabral, former plantation workers of Novo Brasil plantation, accepted their settlement at Água Bobó, they were angry that after years of subsequently extended contracts, their bonus was considerably reduced; thus the workers expressed a sense of betrayal, but the labour inspector claimed that everything was correct and nothing needed to be changed. $\frac{104}{}$ João Franco Ferreira had fled from Água-Izé plantation, had then worked at other plantations, extended his contracts there for seven years, paid his native taxes and finally reached the position of officer of the rural police at Caixão Grande; he also tried to get his bonuses. The inspector general on hearing his claim accused Ferreira of false testimony. $\underline{105}$

The limits of the generosity of the labour inspectorate were therefore clear. They are expressed in the reaction on petitions from workers who were repatriated and now complained about mistreatment and miserable bonus payments. A striking example is the protest by former Cape Verdean worker at Amparo II plantation, Raimundo de Almeida, returned to São Nicolau Tolentino in Santiago Island, Cabo Verde, who reminded the Governor of São Tomé e Príncipe

who certainly knows the life that the contract workers have, in the plantations, will see that it is unfair that an Administrator, as well as obliging the workers into forced labour, under the burning sun, rain, whipping etc. etc., does further damage to them with regard to their salaries.

Almeida claimed he had received only 650 of the 2616 Escudos of bonus he was due. 106 Labour inspector Manuel Cruz Alvara explained that Almeida had misunderstood the Decree of 1931 that halved wages and that 
concerning mistreatment mentioned by that worker in the annexed request, I cannot say anything, especially as they are presented in a vague and imprecise form, which does not allow the formulation of any concrete complaint. $\frac{107}{}$

But the cases in which the labour inspectorate gave a negative response are only one side of the coin. It is obvious that a good number of demands were accepted in the frantic quest to stabilize the workforce. Therefore, during the crisis years, which are mostly known for their violent conditions, a number of labourers nevertheless had a chance to improve their situation through their own agency.

The case of the years of the Great Depression in the archipelago of São Tomé e Príncipe allows for new insights into the complexities of colonial repression and the contradictory effects of the crisis on plantation capitalism with a partly coerced labour force. The authoritarian Portuguese colonial state reacted to the cocoa export crisis by halving the official wage rates, tolerating the manipulation of contract extensions, and turning a blind eye in some cases to increased brutality in labour processes on the plantations. Economic decline and misery for the workers were thus acceptable if that helped the agricultural firms and white plantation managements. These decisions seemed to take into account a heightened level of discontent and resistance in all forms amongst the workers. The increase in repressive punishment was also part of the picture.

Research to date has normally presented the experience of São Tomean plantation society in the $1930 \mathrm{~s}$ as a more extreme variant of exploitative capitalism under colonial rule, relying on a mixture of colonial coercion and repression, elements of coolie migrant labour systems as they existed in other plantation zones, and organization forms that were at least reminiscent of Atlantic slavery before 1888. But the experience of the 1930s also shows the effects of the internal contradictions of colonialism, through the existence of the labour inspectorate. Although the curadores seemed at first glance to be a simple instrument of plantation owners' interests, the crisis situation pushed them to react, if in inconsistent ways. Although the inspectors endorsed the need to lower wages, they became more adamant in insisting on what they regarded as 'good standards'. This meant complaints against white plantation staff regarding corporal punishment, mistreatment of workers, and what inspectors saw as inadequate food and medical health standards, bringing them into conflict with the plantation management. While many of the initiatives taken by the curadoria were unsuccessful, the theme of plantation managers failing in their obligations reappeared repeatedly, creating an atmosphere of social disaster. It was 
on this platform, against a backdrop of social reform attempts within Portuguese colonialism, that relatively steady improvement was made after 1945.

At the same time, workers took advantage of the conflict between inspectorate and plantation managements for their own benefit. Strategic flight was frequent in the 1930s, but runaway workers then managed to hide in São Tomé town and to renegotiate their status, or to find work in other plantations and then to normalize their conditions. While other labourers responded to desperate conditions with individual or group revolt, the effects of workers' agency in local renegotiation - with the inspectorate, not with the manager - must not be underestimated.

Even as an extreme case, the experience of plantation workers in São Tomé e Príncipe can therefore be regarded as instructive for adaptation under social decline during the Great Depression in sub-Saharan African colonial export production zones. Workers suffered from a reduction in salaries, greater exploitation, and more repressive responses to complaints and resistance. However, they also found a platform to improve their living conditions, by using the contradictions of the system, the unclear standards of state institutions accompanying the labour processes and the new worries of individual European inspectors to their advantage. While the Portuguese empire remains a peak of the iceberg of colonial brutalities and repression in the 1930s, and the archipelago of São Tomé e Príncipe a scandalous case within a mainstream of such repression, this case shows both the agency of local African workers, through flight and subaltern methods, and the attempts of a part of the colonial apparatus to come to reforms and improvements. Together with the experience of the war years between 1940 and 1945, these experiences changed the general mood - in São Tomé e Príncipe and in other parts of Africa under colonialism.

\section{Notes}

1 Inspector-General for Plantation Labourers and Natives (Curador-Geral dos Serviçais e Indigenas; the title changes occasionally throughout the 1930s) to Ricardo Vaz Monteiro, Governor of São Tomé e Príncipe (without number), date missing (probably February 1934), 193 (cota 3.17.3.18), Curadoria Geral dos Serviçais e Indígenas (hereafter CGSI), Arquivo Histórico de São Tomé e Príncipe (hereafter AHSTP).

2 J. Ball, “"Alma Negra” (Black Soul): The Campaign for Free Labor in Angola and São Tomé, 1909-1916', Portuguese Studies Review, 18, 1 (2010), 51-72; C. Higgs, Chocolate Islands: Cocoa, Slavery, and Colonial Africa (Athens, OH 2012); L. 
Satre, Chocolate on Trial: Slavery, Politics, and the Ethics of Business (Athens, $\mathrm{OH}$ 2005). In spite of Ball's excellent credentials as a scholar of Angola in the twentieth century, none of these works allows for a more systematic understanding of repressive labour organization in the archipelago, beyond the information used for the campaign.

3 On the labour inspectors, see also M. N. Ceita, 'Para uma história da Curadoria Geral dos Serviços dos Colonos de S. Tomé e Príncipe: 1875-1926,' unpublished MA dissertation, Universidade de Lisboa (2006).

4 S. M. Martin, 'The Long Depression: West African Export Producers and the World Economy, 1914-45', in I. Brown (ed.), The Economies of Africa and Asia in the Interwar Depression (Abingdon/New York 1989), 75-94.

5 Inspector-General for Plantation Labourers and Settlers (the title varies), to Luís Augusto Vieira Fernandes, Governor of São Tomé e Príncipe (without number), 6 January 1933, 193 (cota 3.19.1.14), CGSI, AHSTP.

6 Ricardo Vaz Monteiro, Governor of São Tomé e Príncipe, to Eduardo Ferreira Viana, Governor-General of Angola ( $\mathrm{n}^{\circ}$ 327/6), 8 May 1934, 193 (cota 3.22.3.23), CGSI, AHSTP; Manuel Pereira Figueira, Director of Services of Civil Administration, Division of Central Services of Native Affairs, of the colony of Mozambique, for InspectorGeneral, to Inspector-General of Plantation Workers and Settlers of São Tomé e Príncipe $\left(\mathrm{n}^{\circ}\right.$ 920/169/2-935), $1^{\text {st }}$ November 1935, 193 (cota 3.17.3.18), CGSI, AHSTP; Fernando Machado, Informação (without number), 11 November 1935, 193 (cota 3.17.3.18), CGSI, AHSTP.

7 See the overview on cocoa cycles and production conditions in S. Kiesow, 'Cocoa Culture on São Tomé and Príncipe: The Rise and Fall of Cocoa on the Islands in the Nineteenth and Twentieth Century,' Agricultural History, 91, 1 (2017), 55-77. The work of the probably most knowledgeable historian of São Tomé e Príncipe's economic history, Maciel Santos, has unfortunately remained widely unfinished and is practically completely in Portuguese. See, however, M. Santos, 'A rentabilidade do cacau de São Tomé e Príncipe - hipóteses de explicação,' Africana Studia, 5 (2002), 181-212.

8 Ricardo Vaz Monteiro, Governor of São Tomé e Príncipe, to Director of General Agency of the Colonies in Colonial Ministry ( $\mathrm{n}^{\circ}$ 454/934), 4 December 1934, 012 (Cota 2.26.5.17), Governo da Colónia de S. Tomé e Príncipe, Vários, AHSTP.

9 Judge of Administrative Fiscal Executions (Juiz das Execuções Fiscais Administrativas) to Administrator of Subdivision (Concelho) of São Tomé (n 66/84), 25 
May 1933, 072 (cota 3.4.2.Cxs. 3.21), Administração do Concelho de S. Tomé, Vários, AHSTP.

10 A. Nascimento, Poderes e quotidiano nas roças de S. Tomé e Príncipe de finais de Oitocentos a meados de Novecentos (Lisbon 2002), 47-8.

11 Nascimento, Poderes, 577-88.

12 P. B. Eyzaguirre, 'Small Farmers and Estates in São Tomé, West Africa', unpublished $\mathrm{PhD}$ thesis, Yale University (1986), 282-4.

13 W. G. Clarence-Smith, 'The Hidden Costs on the Cocoa Plantations of São Tomé and Príncipe, 1875-1914', Portuguese Studies, 6, 1 (1990), 152-72.

14 Nascimento, Poderes, 361-3.

15 Santos, 'Rentabilidade', 184.

16 See also M. Macedo, 'Império de cacau: ciência agrícola e regimes de trabalho em São Tomé no início do século XX', in M. Bandeira Jerónimo (ed.), O Império Colonial em Questão (sécs. XIX-XX) (Lisbon 2012), 289-316.

17 The problems of the labour inspectorate in terms of lack of material resources, especially of vehicles to visit plantations, are a feature of the 1930s, see Inspector-General of Plantation Workers and Settlers to Ricardo Vaz Monteiro (without number), 6 January 1933 (1934?), 193 (cota 3.19.1.14), CGSI, AHSTP; Inspectorate-General of Plantation Workers and Settlers in São Tomé e Príncipe, Proposta a Sua Exa. o Governador (without number), without date, 193 (cota 3.19.1.14), CGSI, AHSTP, 1; Inspector-General of Plantation Workers and Settlers in São Tomé e Príncipe, Informação a Sua Ex ${ }^{a}$ o Governador, (without number), 21 February 1935, 193 (cota 3.17.3.18), CGSI, AHSTP, 2 (about visit of plantations on horseback). In 1934, the labour inspectorate was housed in a building shared with a primary school, leading to a number of rather comic or absurd reports, see Inspectorate-General of Plantation Workers and Settlers of São Tomé e Príncipe, Informação a Sua Exa. o Governador, (without number), 5 June 1934, 193 (cota 3.19.1.14), CGSI, AHSTP, 1.

18 On the (Angolan) context, see M. C. Neto, 'A República no seu estado colonial: combater a escravatura, estabelecer o "indigenato", Ler História, 59 (2010), 205-25.

19 M. Newitt, Portugal in Africa: The Last Hundred Years (London 1981); A. Keese, Living with Ambiguity: Integrating an African Elite in French and Portuguese Africa, 1930-1961 (Stuttgart 2007).

20 Inspector-General for Plantation Labourers and Natives to Luís Augusto Vieira Fernandes (without number), 6 January 1933, 193 (cota 3.19.1.14), CGSI, AHSTP, 2. 
21 G. Seibert, Camaradas, Clientes e Compadres: Colonialismo, Socialismo e Democratização em São Tomé e Príncipe (2 ${ }^{\text {nd }}$ ed., Lisbon 2002).

22 A. Keese, 'Early Limits of Local Decolonisation: Forced Labour, Decolonisation and the "Serviçal" Population in São Tomé and Príncipe from Colonial Abuses to PostColonial Disappointment, 1945-1976', International Journal of African Historical Studies, 44, 3 (2011), 373-92; ibid., "Forced labour in the "Gorgulho Years": Understanding Reform and Repression in Rural São Tomé e Príncipe, 19451953', Itinerario, 38, 1 (2014), 103-24.

23 An example of profiting from oral evidence for reconstructing the later Cape Verdean experience is A. Nascimento, Vidas de S. Tomé segundo vozes de Soncente (Praia 2008); far less convincing are Eyzaguirre, 'Farmers', 18-9; and M. Berthet, 'Forced Labor and Migration in São Tomé and Príncipe: Cape Verdean Exile in Poetry and Song,' in N. R. Carpenter and B. N. Lawrance (eds), Africans in Exile: Mobility, Law, and Identity (Bloomington, IN 2018), 219-33.

24 Interview with A. C. F. (anonymised), Rosema Plantation, São Tomé e Príncipe, 16 March 2018.

25 R.A. Austen, 'Colonialism from the Middle: African Clerks as Historical Actors and Discursive Subjects', History in Africa, 38 (2011), 21-33.

26 A. Keese, "Proteger os pretos": Havia uma tendência reformista na administração portuguesa de África Tropical, 1926-1961?', Africana Studia, 6 (2003), 97-125.

27 F. Tavares Pimenta, Angola, os Brancos e a Independência (Porto 2008), 137-41.

28 Afonso de Barros, Acting Inspector-General for Contract Labourers and Natives, to Ricardo Vaz Monteiro, Governor of São Tomé e Príncipe (nº 6), 31 March 1936, 140 (cota 3.3.3.7.), CGSI, AHSTP, 20.

29 W.G. Clarence-Smith, 'Labour Conditions in the Plantations of São Tomé and Príncipe, 1875-1914', Slavery and Abolition, 14, 1 (1993), 149-67; M. Bandeira Jerónimo, The 'Civilising Mission' of Portuguese Colonialism, 1870-1930 (London 2015 [orig. Lisbon 2010]).

30 J. Ball, Angola's Colossal Lie: Forced Labor on a Sugar Plantation, 19131977 (Leiden/Boston 2015); E. Allina, Slavery by Any Other Name: African Life under Company Rule in Colonial Mozambique (Charlottesville/London 2012).

31 Ball, Lie, 88-114; Z. Kagan Guthrie, Bound for Work: Labor, Mobility, and Colonial Rule in Central Mozambique, 1940-1965 (Charlottesville/London 2018), 145-7; see, however, A. Keese, 'The Constraints of Late Colonial Reform Policy: Forced Labour 
Scandals in the Portuguese Congo (Angola) and the Limits of Reform under Authoritarian Colonial Rule, 1955-1961', Portuguese Studies, 28, 2 (2012), 186-200, 189-91.

32 M. Bandeira Jerónimo and J. P. Monteiro, 'Colonial Labour Internationalized: Portugal and the Decolonization Momentum (1945-1975)', International History Review, 42, 3 (2020), 485-504, 496-9; J. P. Monteiro, Portugal e a questão do trabalho forçado: um império sob escrutínio (1944-1962) (Lisbon 2018).

33 A. Freudenthal, 'A Baixa de Cassanje: algodão e revolta', Revista Internacional de Estudos Africanos, 18-22 (1995-1999), 245-83.

34 Keese, 'Limits', 385.

35 S. Coghe, 'Reordering Colonial Society: Model Villages and Social Planning in Rural Angola, 1920-45', Journal of Contemporary History, 52, 1 (2017), 16-44.

36 See G. Austin, 'Vent for Surplus or Productivity Breakthrough? The Ghanaian Cocoa Take-off, c. 1890-1936,' Economic History Review, 67, 4 (2014), 1035-64; J.-P. Chauveau, 'Côte d'Ivoire Pioneer Fronts: Historical and Political Determinants of the Spread of Cocoa Cultivation,' in W.G. Clarence-Smith (ed), Cocoa Pioneer Fronts since 1800: The Role of Smallholders, Planters and Merchants (Basingstoke/London/New York 1996), 176-94.

37 R. Alence, 'The 1937-1938 Gold Coast Cocoa Crisis: The Political Economy of Commercial Stalemate,' African Economic History, 19 (1990/91), 77-104; R. Alence, 'Colonial Government, Social Conflict and State Involvement in Africa's Open Economies: The Origins of the Ghana Cocoa Marketing Board, 1939-46', Journal of African History, 42, 3 (2001), 397-416.

38 C. Coquery-Vidrovitch, 'Afrique coloniale française et la crise de 1930: crise structurelle et genèse du Rapport d'ensemble', Revue française d'histoire d'outre-mer, 63, 232-3 (1976), 386-424.

39 For commercial agriculture in Northern Rhodesia, current-day Zambia, see M. H. Y. Kaniki, 'The Impact of the Great Depression on Northern Rhodesia', Transafrican Journal of History, 24 (1995), 131-50; for 'native settlement' and 'native concentrations' as means in Tanzania to tackle the crisis, see B. Swai, 'Tanganyika and the Great Depression 1929-1936', Transafrican Journal of History, 9, 1-2 (1980), 192-225. For South Africa, the research carried out is also relatively old: A. Minnaar, 'The Effects of the Great Depression on South African White Agriculture', South African Journal of Economic History, 5, 2 (1990), 83-108. 
40 M. E. Ochonu, Colonial Meltdown: Northern Nigeria in the Great Depression (Athens, OH 2009).

41 M. E. Ochonu, 'Critical Convergence: The Great Depression and the Meshing of Nigerian and British Anti-Colonial Polemic', Canadian Journal of African Studies, 43, 2 (2009), 245-81.

42 See J. W. Cell, 'Lord Hailey and the Making of the African Survey', African Affairs, 88, 353 (1989), 481-505; and C. Coquery-Vidrovitch, 'The Popular Front and the Colonial Question in French West Africa: An Example of Reformist Colonialism', in Tony Chafer and Amanda Sackur (eds), French Colonial Empire and the Popular Front: Hope and Disillusion (Basingstoke 1999), 155-69.

43 Afonso de Barros, Acting Inspector-General for Contract Labourers and Natives, to Ricardo Vaz Monteiro, Governor of São Tomé e Príncipe (nº 6), 31 March 1936, 140 (cota 3.3.3.7.), CGSI, AHSTP, 9-10.

44 Ibid., 10.

45 Inspector-General for Contract Labourers and Natives, Informação a Sua Excelência o Governador da Colónia: (without number), 12 April 1935, 193 (cota 3.17.3.18), CGSI, AHSTP. However, such resettlements were relatively limited in number, as for workers from Monte Rosa (concerning 32 workers) or from Guaiaquil plantation.

46 Fernando Costa, Administrator of Companhia Agrícola das Neves, to InspectorGeneral for Contract Labourers and Natives (without number), 28 February 1931, 193 (cota 3.27.2.24), CGSI, AHSTP.

47 Inspector-General for Contract Labourers and Natives to Director of Cabinet Division of São Tomé e Príncipe (n ${ }^{\circ} 657 / 110 / 1^{\mathrm{a}}$.), 4 October 1937, 820 (cota 2.35A.1.Cx-1.2, antiga cota 2.23.7.Cx-2.2), CGSI, AHSTP.

48 Manuel Pinho da Silva, Administrator-Agriculturalist of Caridade Plantation, Relação dos tongas do sexo masculino existentes nesta propriedade, de concordância com a circular $n^{\circ}$ 2, da Curadoria Geral, datada de 21 deste mez. (without number), 30 March 1935, 193 (cota 3.17.3.18), CGSI, AHSTP; for the example of a small roça such as Guegue, with 10 tongas and 9 plantation workers with fixed residence, see Administrator of Guegue Plantation to Inspector-General of Contract Labourers and Natives (without number), 30 March 1935, 193 (cota 3.17.3.18), CGSI, AHSTP.

49 De Santos, Administrator of Monte Café Plantation, Roça Monte Café - Serviço do Imposto Individual (without number), 28 March 1935, 193 (cota 3.17.3.18), CGSI, AHSTP. 
50 Aimé Palanque, Administrator of Santa Catarina Plantation, Relação dos serviçais com Residencia Fixada, a que se refere a Circular $N^{\circ} 2$, de 21 do corrente: (without number), 27 March 1935, 193 (cota 3.17.3.18), CGSI, AHSTP; Palanque, Relação dos Tongas a que se refere a Circular $N^{\circ}$ 2: (without number), 27 March 1935, 193 (cota 3.17.3.18), CGSI, AHSTP.

51 Roça 'Agua-Izé' - Relação dos Tongas em conformidade com as folhas de pagamento (without number), without date, 193 (cota 3.17.3.18), CGSI, AHSTP.

52 J. Guedes L. ${ }^{\text {da }}$, Roça Java, Relação de Serviçais com Residencia Fixa, existentes nesta Propriedade (without number), 28 March 1935, 193 (cota 3.17.3.18), CGSI, AHSTP; Administrator of Blu-Blu Plantation to Inspector-General for Contract Workers and Settlers (without number), 25 March 1935, 193 (cota 3.17.3.18), CGSI, AHSTP and Januário José da Silva Júnior, Administrator of Monte Leão Plantation, to InspectorGeneral (without number), 8 March 1935, 193 (cota 3.17.3.18), CGSI, AHSTP; Joaquim Alves Mota, Administrator of Cangã Plantation, to Inspector-General (without number), 6 April 1935, 193 (cota 3.17.3.18), CGSI, AHSTP.

53 Afonso de Barros to Ricardo Vaz Monteiro (n 6), 31 March 1936, 140 (cota 3.3.3.7.), CGSI, AHSTP, 8.

54 Administrator of Água-Izé Plantation, to Inspector-General for Contract Workers and Settlers (without number), 11 May 1934, 193 (cota 3.17.5.8), CGSI, AHSTP.

55 Pedro Gomes de Abreu, Administrator of Companhia Ilha de São Tomé, to Fernando da Sousa Guedes Machado, Acting Inspector-General for Contract Workers and Settlers (without number), 13 November 1936, 140 (cota 3.3.3.7.), CGSI, AHSTP; Da Sousa Guedes Machado to Administrator of Companhia Ilha de São Tomé, Roça Dona Augusta ( $\left.\mathrm{n}^{\circ} 1^{\mathrm{a}} . / 1936 / 11 / 1\right), 11$ November 1936, 140 (cota 3.3.3.7.), CGSI, AHSTP.

56 Da Sousa Guedes Machado to Administrator of Companhia Ilha de São Tomé, Angolares Plantation ( $\left.\mathrm{n}^{\circ} 1^{\mathrm{a}} . / 12 / 2\right)$ ), 10 December 1936, 140 (cota 3.3.3.7.), CGSI, AHSTP.

57 João Marquês Cana, Chief Analyst of the Section of Chemistry, Bromatology and Toxicology of the General Laboratory of Analyses of São Tomé, Análise do valor alimentar de uma refeição de manhã distribuida a um trabalhador indigena, que foi enviada á Repartição de Serviços de Saúde e Higiéne com a nota da Curadoria Geral dos Serviçais e Colonos, $n^{\circ}$ 591/23, de 9 do corrente, (without number), 17 August 1934, 193 (cota 3.17.5.8), CGSI, AHSTP. 
58 José de Vasconcelos e Sá Guerreiro Nuno, Scribe at the Inspectorate-General for Contract Workers and Settlers, Autos de transgressão do art. ${ }^{\circ} 346$ do C.T.I. - Queixoso ou participante Os serviçais da Roça São Nicolau de nomes Bie, angolano, Magalhães, angolano, e Uaseria, moçambicano - Arguido João Graça, europeu, encarregado da Roça São Nicolau. - Auto de Noticia (without number), 13 August 1937, 965 (cota 3.16.5.11), CGSI, AHSTP.

59 José Luís Dão, Director of the Administrative Section of the Services of Health and Hygiene, Informação: Assunto: Acerca do Despacho de Sua Excelência o Governador, de vinte e seis do corrente, que manda ouvir a Repartição de Saúde, sobre os Serviços de Assistência Particular prestada palos [sic] Médicos desta Repartição a Serviçais da Curadoria. (n 73), 28 March 1934, 193 (cota 3.17.5.8), CGSI, AHSTP.

60 Acting Inspector-General for Contract Workers and Settlers to Managers of Anibal da Silva \& Gouveia Lda. (n 747/203), 3 June 1932, 207 (cota 3.22.4.25), CGSI, AHSTP. 61 Acting Inspector-General for Contract Workers and Settlers to Managers of Caridade Plantation, Gouveia Ltda \& Anibal da Silva \& Gouveia Lda. (n ${ }^{\circ}$ 230/292), 18 October 1932, 207 (cota 3.22.4.25), CGSI, AHSTP.

62 Inspector-General for Contract Workers and Settlers, Informação a Sua Exa o Governador, (without number), 11 March 1935, 193 (cota 3.17.3.18), CGSI, AHSTP; Afonso de Barros, First official of the Labour Inspectorate, Copia do termo de identificação da serviçal de nome Rosa Maria, natural de S. Tomé, da Roça Boa Entrada, que consta a folhas sessenta e sete verso e seguintes, do respectivo livro de identificação desta Curadoria. (without number), 7 March 1935, 193 (cota 3.17.3.18), CGSI, AHSTP. 63 António Ferreira, Manager of Amparo Plantation, Société Anonyme Plantations 'Amparo' à San-Thomé et Produits Coloniaux, to Inspector-General of Contract Workers and Settlers (without number), 10 March 1934, 193 (cota 3.17.5.8), CGSI, AHSTP.

64 AHSTP, CGSI, 140 (cota 3.3.3.7.), Captain Manuel do Rosário Curado, Agent of the Inspector-General at Príncipe, to Inspector-General for Contract Workers and Natives $\left(\mathrm{n}^{\circ}\right.$ 141), 22 October 1936, 1.

65 Afonso de Barros, to Governor of São Tomé e Príncipe (n 6/1), 4 May 1936, 140 (cota 3.3.3.7.), CGSI, AHSTP.

66 [Comentário situação administrativa de São Tomé e Príncipe] (only middle page, missing number, missing date [1934?]), 193 (cota 3.26.2.17), CGSI, AHSTP. On the shortcomings of the police force, especially the fact that the sub-officer was a Guinean who spoke little Portuguese, see also Curadoria Geral dos Serviçais e Indígenas 
[Inspectorate-General of Plantation Workers and Natives], Informação a Sua Exa o Governador, (without number), 25 February 1935, 193 (cota 3.17.3.18), CGSI, AHSTP, 2.

67 Afonso de Barros, Acting Inspector-General of Contract Workers and Natives, to Ricardo Vaz Monteiro, Informação (n 8), 28 April 1936, 140 (cota 3.3.3.7.), CGSI, AHSTP, 1.

68 Administrator of Milagrosa Plantation (of Companhia das Roças Plateau e Milagrosa), to Inspector-General for Contract Workers and Settlers (without number), 9 January 1931, 193 (cota 3.27.2.24), CGSI, AHSTP.

69 Depositary of the Possessions of Sociedade Agrícola Praia Nazareth, Lda., for Banco Nacional Ultramarino, to Inspector-General for Contract Workers and Settlers (without number), 28 June 1935, 193 (cota 3.17.3.18), CGSI, AHSTP.

70 Inspector-General for Contract Workers and Natives, Informação a Sua Exa o Governador: (without number), 20 February 1935, 193 (cota 3.17.3.18), CGSI, AHSTP.

71 João Ferreira, Anibal da Silva \& Gouveia Lda., to Acting Inspector-General for Contract Workers and Natives (without number), 9 October 1932, 207 (cota 3.22.4.25), CGSI, AHSTP.

72 Commander of the Portuguese Armed Forces in São Tomé e Príncipe to InspectorGeneral for Contract Workers and Settlers (without number), 23 October 1934, 193 (cota 3.19.1.14), CGSI, AHSTP, 1-2.

73 Acting Inspector-General for Contract Workers and Natives to Ricardo Vaz Monteiro (page number unclear, first page missing), 10 July 1935, 193 (cota 3.17.3.18), CGSI, AHSTP.

74 Aimé Palanque, Administrator of Companhia Terras de Santa Catarina, to InspectorGeneral for Contract Workers and Settlers (without number), 12 August 1931, 193 (cota 3.27.2.24), CGSI, AHSTP.

75 Fernando Quintas de Carvalho, Administrator of Favorita Plantation, to InspectorGeneral for Contract Workers and Settlers (without number), 27 March 1934, 193 (cota 3.22.3.23), CGSI, AHSTP.

76 Carlos Sampaio, Inspector-General for Contract Workers and Settlers, to Manoel Bernardo Ferreira, Administrator of Santa Margarida Plantation (without number) 28 February 1934, 193 (cota 3.19.1.14), CGSI, AHSTP, 1. 
77 Administrator of Montes Hermínios Plantation to Inspector-General for Contract Workers and Settlers (without number), 13 March 1931, 193 (cota 3.27.2.24), CGSI, AHSTP.

78 Commander of First Section to Inspector-General for Contract Workers and Settlers, Informação (without number), 2 March 1934, 193 (cota 3.22.3.23), CGSI, AHSTP.

79 Administrator of Milagrosa Plantation (of Companhia das Roças Plateau e Milagrosa), to Inspector-General for Contract Workers and Settlers (without number), 15 July 1931, 193 (cota 3.27.2.24), CGSI, AHSTP; Administrator of Milagrosa Plantation to InspectorGeneral for Contract Workers and Settlers (without number), 17 July 1931, 193 (cota 3.27.2.24), CGSI, AHSTP.

80 Administrator of Montes Hermínios Plantation to Inspector-General for Contract Workers and Settlers (without number), 2 April 1931, 193 (cota 3.27.2.24), CGSI, AHSTP; Acting Administrator of Sociedade Civil Agrícola Roça Boa Nova to InspectorGeneral for Contract Workers and Settlers (without number), 24 February 1934, 193 (cota 3.22.3.23), CGSI, AHSTP.

81 Administrator of Favorita Plantation to Inspector-General for Contract Workers and Settlers (without number), 24 June 1931, 193 (cota 3.27.2.24), CGSI, AHSTP.

82 Ignácio Pinto da Rocha, Administrator of Queluz Plantation, to Inspector-General for Contract Workers and Settlers (without number), 7 August 1931, 193 (cota 3.15.3.26), CGSI, AHSTP, 1-2.

83 Director of Division of Health to Inspector-General for Contract Workers and Settlers (n 117), 27 February 1935, 193 (cota 3.17.3.18), CGSI, AHSTP.

84 Inspector-General for Contract Workers and Settlers to Administrator of Lembá Plantation (without number), 11 December 1930, 193 (cota 3.1.3.12), CGSI, AHSTP.

85 António Antunes, Administrator of São Nicolau Plantation, to Inspector-General for Contract Workers and Settlers (without number), 25 March 1934, 193 (cota 3.22.3.23), CGSI, AHSTP.

86 Joaquim de Almeida, Administrator of Filipina Plantation (of Mendes Lopes, Lda.), to Inspector-General for Contract Workers and Settlers (without number), 22 January 1931, 193 (cota 3.27.2.24), CGSI, AHSTP.

87 Inspector-General for Contract Workers and Settlers to Administrator of Água Izé Plantation (without number), 24 January 1934, 193 (cota 3.19.1.14), CGSI, AHSTP. 
88 Administrator of Praia das Conchas Plantation to Inspector-General for Contract Workers and Settlers (without number), 19 September 1934, 193 (cota 3.22.3.23), CGSI, AHSTP.

89 Afonso de Barros, Acting Inspector-General for Contract Workers and Settlers to Ricardo Vaz Monteiro, Informação (n 8), 28 April 1936, 140 (cota 3.3.3.7.), CGSI, AHSTP.

90 Acting Inspector-General for Contract Workers and Settlers to Administrator of Colónia Açoriana Plantation (without number), 8 December 1930, 193 (cota 3.1.3.12), CGSI, AHSTP.

91 Acting Inspector-General for Contract Workers and Settlers to Administrator of Jou Plantation (without number), 15 October 1930, 193 (cota 3.1.3.12), CGSI, AHSTP.

92 Acting Inspector-General for Contract Workers and Settlers to Administrator of São Nicolau Plantation (without number), 27 March 1934, 193 (cota 3.19.1.14), CGSI, AHSTP.

93 Acting Inspector-General for Contract Workers and Settlers to Administrator of Aliança Plantation (without number), 23 March 1934, 193 (cota 3.19.1.14), CGSI, AHSTP.

94 Acting Labour Inspector to Managers of Anibal da Silva \& Gouveia Lda. (n 600/185), 2 May 1932, 207 (cota 3.22.4.25), CGSI, AHSTP.

95 Acting Inspector-General for Contract Workers and Settlers to Administrator of Jou Plantation (without number), 15 October 1930, 193 (cota 3.1.3.12), CGSI, AHSTP.

96 Fernando de Sousa Guedes Machado, Acting Inspector-General for Contract Workers and Settlers to Administrator of Bela Vista Plantation ( ${ }^{\circ}$ 220/88), 26 April 1938, 207 (cota 3.8.5.9), CGSI, AHSTP.

97 A. Ribeiro, Administrator of Pinheira Plantation (part of Companhia D. Aurora de Macedo), to Inspector-General for Contract Workers and Settlers (without number), 15 September 1931, 193 (cota 3.27.2.24), CGSI, AHSTP.

98 Acting Inspector-General to Commander of the Corps of Native Police ( ${ }^{\circ}$ 928/233), 4 July 1932, 207 (cota 3.22.4.25), CGSI, AHSTP.

99 Manuel do Oeste Pinheiro, Administrator of Jou Plantation, to Acting InspectorGeneral for Contract Workers and Settlers (without number), 11 February 1931, 193 (cota 3.27.2.24), CGSI, AHSTP, 1.

100 Aimé Palanque, Administrator of Companhia Terras de Santa Catarina, to InspectorGeneral for Contract Workers and Settlers (without number), 12 August 1931, 193 (cota 
3.27.2.24), CGSI, AHSTP; José Curado, Administrator of Novo Brasil Plantation, to Inspector-General (without number), 9 February 1932, 207 (cota 3.22.4.25), CGSI, AHSTP.

101 Afonso de Barros, First Official of the Labour Inspectorate, Copia do termo de identificação da serviçal de nome Rosa Maria, natural de S. Tomé, da Roça Boa Entrada, que consta a folhas sessenta e sete verso e seguintes, do respectivo livro de identificação desta Curadoria. (without number), 7 March 1935, 193 (cota 3.17.3.18), CGSI, AHSTP, 1.

102 Inspector-General for Contract Workers and Settlers to Luís Augusto Vieira Fernandes (without number), 6 January 1933, 193 (cota 3.19.1.14), CGSI, AHSTP, 3.

103 Xibia to Inspector-General for Contract Workers and Settlers, Petição de Tehibia ou Xibia, natural de Angola, assinada por outra persona porque no sabia escrever (signed by witness João Leão) (without number), 15 November 1934, 193 (cota 3.19.1.14), CGSI, AHSTP.

104 Barros to Inspector-General for Contract Workers and Settlers, Petição de Luiza Cabral e seu filho Joaquim Cabral, assinada por Manuel da Trindade de Barros pelos requerentes (without number), 8 November 1934, 193 (cota 3.19.1.14), CGSI, AHSTP. 105 Espírito Santo to Inspector-General for Contract Workers and Settlers, Petição de

João Franco Ferreira, assinada pelo requerente Marco de Espirito Santo (without number), 19 June 1934, 193 (cota 3.19.1.14), CGSI, AHSTP.

106 Raimundo de Almeida to Ricardo Vaz Monteiro (without number, writing from Praia), 4 November 1938, 193 (cota 3.9.2.23), CGSI, AHSTP (quote on 2).

107 Manuel da Cruz Alvara, Inspector-General of Contract Workers and Settlers, to Ricardo Vaz Monteiro, Informação: requerimento de Raimundo de Almeida que acompanhou o oficio n. 293 do Governo da Colónia de CaboVerde. (without number), 13 March 1939, 193 (cota 3.9.2.23), CGSI, AHSTP.

\section{Acknowledgements}

This work was financed by FEDER - COMPETE 2020 - POCI and by FCT - Fundação para a Ciência e a Tecnologia, in relation to the research project "Worlds of (under)development: Processes and legacies of the Portuguese colonial empire in a comparative perspective (1945-1975)" (POCI-01-0145-FEDER-031906). 
The authors would like to thank Allainy Sousa of the Arquivo Histórico de São Tomé e Príncipe for his marvellous support over more than a decade of research stays, and Miguel Bandeira Jerónimo for his attentiveness and patience in accompanying the way to this research output.

\section{Biographical Note}

Beatriz Valverde Contreras is a postdoctoral research fellow in the Centro de Estudos Sociais of the Universidade de Coimbra, Portugal. She is the author of El Orgullo de la Nación: La Creación de la Identidad Nacional en las Conmemoraciones Culturales Españolas (Madrid 2015). She currently works in a project on the late colonial history of Portuguese colonialism, especially in Angola.

Alexander Keese is a professor of African history at the Universite de Genève, Switzerland. $\mathrm{He}$ is the author of Ethnicity and the Colonial State: Finding and Representing Group Identifications in a Coastal West African and Global Perspective (Leiden 2016). His article publications include nine English-language journal articles on the history of Angola, Cabo Verde and São Tomé e Príncipe. 